\title{
Research on rabbit feeding and nutrition development during the last 20 years and in the future
}

\author{
F. LEBAS \\ Laboratoive de Recherches sur l'Elevage du Lapin, \\ I.N.R.A., Toulouse, \\ B.P. I2 - 31320 Castanet Tolosan (France)
}

A review of $25^{\circ}$ original articles on rabbit feeding published between 1959 and 1978 , shows that the yearly number of papers increases irregularly (fig. I). Nutrition of breeding rabbits is poorly represented with only $\mathrm{I} 6 \mathrm{p}$. 100 of the total. The principal subject of those publications is protein nutrition, mainly since 1970 . On the contrary the number of publications on minerals is regressing (fig. 3 ).

Many studies are made with a very small ( 5 to Io) number of rabbits. Thus, performances differing as much as $5_{5}$ to $20 \mathrm{p}$. 100 from each others are considered to be equivalent. The practical consequence is the lack of an accurate estimation of the requirements. Variations of the feed quality are also responsible for a part of the variability between observed performances obtained with the "same " diet.

Practical recommandations for feed composition may in some cases be different from the true minimum requirements. This is caused by the absence of knowledge about interactions between nutrients. Practical recommandations are proposed (Tab1. 5).

During the next io years it would be of great interest for scientists and rabbit producers that the maximum difference between performances considered as equivalent be progressively reduced from the present $\mathrm{I} 3 \mathrm{p}$. Ioo to 5 and $2-3 \mathrm{p}$. I oo. This can easily be obtained by increasing the number of animals allocated to the experiments. Efficiency of research on rabbit feeding may also be improved if the period of observation is long enough as compared to the practical fattening or reproduction length. It would perhaps be of some interest to consider 2 or 3 periods between weaning and slaughter.

Because of the high capacity of rabbits to transform dietary nitrogen into meat protein, work on nitrogen nutrition should be developped. Digestibility of crude fibre by rabbits is very low as compared with other herbivorous animals, but they may eat very large amounts of crude fibre. Thus, rabbits are able to use very efficiently plants and other materials with a high level of both protein and fibre. This will be a good direction for research on rabbit nutrition during the next ro years.

\section{II. - SHORT REPORTS}

\section{Artificial feeding of young rabbits between birth and weaning}

\author{
C. BACQUES, J. P. PERRET et A. DORIER \\ Laboratoire de Nutrition \\ Institut Universitaire de Technologie \\ 43, bd du II novembre I9I8 \\ 60621 Villeurbanne (France)
}

The diet used for young rabbits before weaning consisted of an autoclaved homogenized mixture of cow's milk calcium caseinate ( $124 \mathrm{~g} / 1$ ) and medium or long chain triglycerides (I I $4 \mathrm{~g} / \mathrm{l}$ ) supplemented with vitamins $A-B-D$, a hormone, trace elements and lipotrophic factors. The phosphorus/calcium and carbohydrate/protein ratios as well as the dry matter level used led to a digestibility coefficient of about $85 \mathrm{p}$. Ioo.

The survival rate of the rabbits after weaning was 80 p. roo. 